\title{
ANALISIS INFORMASI AKUNTANSI DIFERENSIAL DALAM PENGAMBILAN KEPUTUSAN PENGGANTIAN AKTIVA TETAP PADA UD. SINGKIL SERVICE MANADO
}

\author{
Juliana Y.P Salasa ${ }^{1}$, Grace B. Nangoi ${ }^{2}$, Sintje Rondonuwu ${ }^{3}$ \\ 1,2,3 Jurusan Akuntansi, Fakultas Ekonomi dan Bisnis, Universitas Sam Ratulangi, Jl.Kampus Bahu, Manado, \\ 95115, Indonesia \\ E-mail : senapratiwi1997@gmail.com
}

\begin{abstract}
In the modern era, there are many innovations created by the company to expand the company's activities, with one of them using fixed like a good machine. But in a fixed condition, companies can see costs such as fees for taking results from the machine. The purpose of this research is to find out how information can be used. The analytical method used in this study is a qualitative descriptive method, where the method of this research is carried out in detail by collecting data from the company and analyzing the results of the analysis. The results of this study are UD. Singkil Service Manado can apply the concept of Differential Accounting Information in decision making. Freezing can be useful for costs that can harm the company. Companies should be able to replace the old machine with a new engine because there is a large enough difference

Keywords: Differential Accounting Information, Replacement of fixed assets.
\end{abstract}

\section{PENDAHULUAN}

Dalam antar tiap-tiap perusahaan saat ini daya saingnya semakin kuat. Baik perusahaan berskala besar maupun usaha kecil menengah dituntut untuk memiliki strategi tersendiri agar perusahaannya tetap berjalan dengan baik dan bisa bersaing dengan perusahan lainnya. Dengan bisa mendapatkan harga yang murah dan hasil output yang berkualitas perusahaan begitu sulit untuk mendapatkannya. Untuk mendapatkannya, perusahaan membutuhkan keahlian dari manajemen agar dapat semaksimal mungkin untuk semua input, demi mendapatkan hasil output yang berkualitas bagi perusahaan.

Dalam hal ini UD.Singkil Service Manado sebagai perusahaan yang bergerak pada bidang jasa yang memberikan jasa mencuci mobil pada konsumen, informasi akuntansi begitu penting untuk pihak manajer dalam mengetahui biaya dan beban pada mesin yang terlalu banyak dihasilkan biasanya penyebab kerugian yang didapatkan dalam perusahaan.

\section{TINJAUAN PUSTAKA Konsep Akuntansi}

Pengertian Akuntansi. Secara umum akuntansi adalah seni dan teknik serta bagian dari cabang ilmu yang mengukur, menguraikan, dan memberikan suatu kepastian untuk manfaat bagi para pemakai akuntansi seperti, manajer, akuntan, auditor dalam memberikan suatu kepastian.

Para Pengguna Akuntansi. Menurut Horngren, Harrison dan Bamber (2006:13) "ada beberapa yang memakai kebutuhan informasi akuntansi dalam membuat keputusan, yaitu : individu, pebisnis, investor, kreditor, badan regulasi pemerintah, dinas pajak, dan organisasi nirlaba. 


\section{Konsep Akuntansi Manajemen}

Pengertian Akuntansi Manajemen. Akuntansi manajemen merupakan dua kata yang di gabungkan yaitu akuntansi dan manajemen, duanya memiliki artian yang berbeda. Akuntansi manajerial atau biasa di sebut akuntansi manajemen merupakan suatu sistem akuntansi yang berfungsi untuk penggunaan informasi akuntasi kepada manajer atau bagian manajemen pada suatu perusahaan juga manajemen untuk dapat membuat suatu keputusan tujuannya agar manajemen dapat mengetahui dan dapat memberikan fungsi kontrol. Menurut Mulyadi (2010:2) " bisa dilihat dari dua prespektif akuntansi manajemen adalah bagian dari tipe akuntansi dan juga akuntansi manajemen. Dalam memberikan keperluan yang dibutuhkan untuk membuat fungsi perencanaan juga dalam pengendalian pihak organisasi semua itu adalah tipe dari akuntansi manajemen”.

Informasi Akuntansi Manajemen. Pihak manajemenen memerlukan informasi akuntansin dalam melakukan Fungsi dari pokok manajemen yaitu dua: pengendalian dan perencanaan aktivitas dalam perusahaan.

Manfaat Informasi Akuntansi Manajemen. Menurut Mulyadi (2014:15), “informasi akuntansi manajemen dapat dihubungkan dalam beberapa hal:

1. Objek informasi, dengan bagian departemen, juga aktivitas, dan hasilnya ialah konsep informasi penuh akuntansi.

2. Opsi yang dipilih, konsep informasi akuntansi diferensial yang didapatkan, pengambilan keputusan yang di ambil oleh manajemen begitu diperlukan.

3. Kewenangan dari manajer, menghasilkan rencana dari informasi akuntansi pertanggungjawaban, manfaat yang didapat dalamnya ialah untuk membangun organisasi dalam perusahaan agar dapat berperilaku dengan baik".

Tipe Informasi Akuntansi Manajemen. Menurut Mulyadi (2010:16) "Secara ringkas konsep kegunaan setiap tipe informasi informasi akuntansi manajemen: informasi akuntansi penuh (full accounting information), informasi akuntansi diferensial (differential accounting information), dan informasi akuntansi pertanggungjawaban (responsibility accounting information)".

Karakteristik Akuntansi Manajemen dan Akuntansi Keuangan. Menurut Mulyadi (2010:3) "dua tipe akuntansi memiliki karakteristik yang berbeda arena disebabkan pemakai informasi yang dihasilkan oleh kedua tipe akuntansi tersebut yaitu, akuntansi keuangan adalah tipe akuntansi yang membuat informasi keuangan terutama agar dapat memenuhi keperluan manajemen puncak dan pihak luar organisasi, sedangkan akuntansi manajemen adalah tipe akuntansi yang membuat informasi keuangan terutama mneghasiklan keperluan manajemen dalam melakukann fungsi perencanaan dan pengendalian"

Konsep Akuntansi Biaya. Menurut Mulyadi (2010:8), "biaya merupakan sumber ekonomi yang di dalam ukur satuan uang, yang kemungkinan akan terjadi atau telah terjadi untuk tujuan tertentu".

Manfaat Akuntansi Biaya. Manfaat akuntansi biaya adalah sebagai berikut yaitu "Menjadi pemasok informasi dasar untuk menentukan harga jual produk barang dan jasa, menjadi bagian dari alat pengendalian manajemen, yang berhubungan dengan pengukuran kinerja manajer pusat pertanggung jawaban dan menjadi alat pamasok informasi untuk pihak eksternal bersamaan dengan seluruh aspek biaya operasi, contoh saja untuk kepentingan pajak".

Perilaku Biaya. Makna perilaku biaya adalah istilah umum untuk menggambarkan apakah biaya masukan (input) aktivitas adalah tetap atau variabel dalam hubungannya dengan perubahan keluaran aktivitas". (Armila 2006:69). Untuk mengetahui bagaimana cara menentukan pola perilaku biaya perlu memperhatikan 3 hal menurut Armila (2006:70), yaitu "Horison Waktu adalah oenting dalam penetapan perilaku biaya karena biaya dapat berubah dari tetap menjadi variable tergantung pada apakah keputusan tersebut untuk jangka pendek 
atau jangka panjang, sumber daya yang tersedia ketika diperlukan Karena biaya sumber daya yang akan digunakan tersedia pada saat diperlukan, perusahaan biasanya hanya membutuhkan sumber daya yang digunakan untuk menghasilkan output, sumber daya yang tersedia sebelumnya (dimuka) banyak sumber daya yang diperoleh melalui pembayaran kas dimuka atau melalui kontrak. Penyewaan bangunan dan oeralatan adalah contoh dari bentuk perolehan sumber daya yang tersedia sebelum penggunaan dapat didefinisikan sebagai biaya tetap".

\section{METODE PENELITIAN}

Jenis Penelitian. Penelitian ini merupakan jenis penelitian yang deskriptif dengan pendekatan kualitatif.

\section{Tempat dan Waktu Penelitian}

Tempat Penelitian. UD.Singkil Service adalah perusahaan jasa yang tempatnya di Singkil, Manado. Perusahaan ini bergerak di bidang jasa dalam melayani pencucian dan perawatan mobil dan motor. J1. Hassanudin, Singkil, Kota Manado.

Waktu Penelitian. Penelitian ini dilaksanakan kurang dari 6 (enam) bulan, dimulai pada awal bulan Maret 2018 sampai dengan selesai.

\section{Jenis data, Sumber data, dan Metode Pengumpulan Data}

Jenis Data. Dalam penelitian ini, jenis data yang digunakan ialah data kualitatif dan kuantitatif.

1. Data kualitatif dalam penelitian ini yaitu berupa uraian mengenai gambaran umum, visi, dan misi bidang usaha dan hasil produksi, serta struktur organisasi UD. Singkil Service.

2. Data kuantitatif dalam penelitian ini berupa data keuangan yang terdiri dari data pembelian, data penjualan, serta biaya-biaya mesin yang digunakan UD.Singkil Service

Sumber Data. Sumber data yang digunakan dalam penelitian ini adalah data primer. Yaitu data yang diperoleh melalui wawancara dan pelaporan biaya pada UD. Singkil Service secara Langsung.

Metode Pengumpulan Data. Metode pengumpulan data yang digunakan dalam penelitian ini, antara lain:

Wawancara. Wawancara akan dilakukan oleh peneliti pada manajer bagian umum dengan mengajukan pertanyaan-pertanyaan terstruktur yang berhubungan dengan objek kajian yang diteliti baik lisan maupun tulisan pada UD. Singkil Service.

Dokumentasi. Dokumentasi yang akan dilakukan oleh peneliti dengan cara mengumpulkan setiap dokumen yang berhubungan dengan objek kajian yang akan diteliti pada UD. Singkil Service.

Metode dan Proses Analisis. Metode analisis deskriptif yang cocok untuk digunakan pada penelitian ini. Karena metode tersebut berbicara atau membahas kegiatan yang diuraikan dan sistematis dari fakta yang terjadi sehingga bisa diberikan kesimpulan dalam menangani masalah yang ada pada sebuah organisasi.

\section{HASIL PENELITIAN DAN PEMBAHASAN}

\subsection{Hasil Penelitian}

Visi UD. Singkil Service adalah menjadi pusat pencucian, penggantian oli, dan salon mobil yang terbaik dan unggul dalam pelayanan. Misi UD.Singkil Service adalah memberikan pelayanan terbaik bagi konsumen. UD.Singkil Service sangat mengutamakan pelayanan jasa yang diberikan serta menjaga kualitas agar konsumen mendapatkan yang terbaik.

Dalam melakukan penelitian ini yaitu menganalisa pengambilan keputusan penggantian aktiva tetap untuk mesin pada perusahaan UD.Singkil Service. Dengan 
menjalankan kegiatan perusahaan ada sejumlah aktiva yang dimiliki UD.Singkil Service dan dalam penelitian ini aktiva tetap yang akan menjadi objek penelitian adalah mesin Hidrolik Mobil yang adalah mesin produksi utama UD.Singkil Service.

Tabel 1. Data dari Mesin Hidrolik

\begin{tabular}{lr}
\hline \multicolumn{1}{c}{ Nama Mesin } & Mesin Hidrolik \\
\hline Harga Beli & Rp.64.000.000 \\
Tahun Pembelian & 2014 \\
Masa Manfaat / Umur Ekonomis & 12 tahun \\
Nilai Residu / Nilai sisa & 0 \\
Nilai buku & RP.42.666.668 \\
Rata-rata pencucian mobil setiap bulan & 25 unit mobil \\
Pendapatan pencucian mobil per bulan & Rp35.750.000 \\
\hline Sumber:
\end{tabular}

Sumber:UD. Singkil Service Manado 2018

Tabel 1 adalah data mesin hidrolik yang didapatkan dari perusahaan dimana menunjukkan bahwa mesin tersebut dibeli dengan harga Rp.64.000.000 dengan mempunyai masa manfaat 12 tahun. Mesin tersebut telah terhitung pada tahun 2018 telah mencapai masa manfaat selama 8 tahun, mesin hidrolik mobil mendapatkan rata pencucian sebanyak 25 unit mobil. Mesin hidrolik dapat menghasilkan pendapatan pertahun Rp.429.000.000. sisa manfaat mesin hidrolik ini yaitu 8tahun.

\subsection{Pembahasan}

Jika dalam hal ini UD.Singkil Service akan memberikan keputusan apakah perusahaan perlu mempertimbangkan kembali agar dapat mengubah atau mengganti mesin yang lama dengan yang baru dengan begitu pihak manajemen sangat membutuhkan teknik dalam menganalisis ekonomi agar dapat memberikan keputusan yang tepat dan tidak merugikan organisasi atau perusahaan,agar dapat memperbaiki efisiensi operasi. Dengan menganalisis sebuah biaya yang bisa membuat masing-masing biaya pendapatan relevan dan penghasilan yang tidak untuk beberapa berusahaan dalam mengambil keputusankonsep "differential cost" adalah dasar dari analisis biaya yang bisa mendapat penggantian aktiva tetap perusahaan. Dari data diatas dapat dihitung penyusutan pertahun dengan menghitung "harga perolehan, nilai residu, dan umur ekonomis dari mesin menggunakaan straight line method" yaitu:

$$
\begin{aligned}
\text { Penyusutan } & =\frac{\text { Harga perolehan }- \text { nilai residu }}{\text { Umur ekonomis }} \\
& =\frac{\operatorname{Rp~} 64.000 .000-0}{8} \\
& =\text { Rp.5.333..332 }
\end{aligned}
$$

Nilai Buku = Harga perolehan- akumulasi penyusutan

$=\operatorname{Rp} \cdot 64.000 .0000-($ Rp.5.333.332x8)

$=$ Rp.64.000.0000 - Rp. 42.666 .656

$=\operatorname{Rp} \cdot 21.333 .344$ 
Tabel 2. Biaya Operasional pada Mesin Hidrolik

\begin{tabular}{lcr}
\hline \multicolumn{1}{c}{ Biaya operasional } & Pertahun & Selama 8tahum \\
\hline $\begin{array}{l}\text { Biaya karyawan dan tenaga } \\
\text { kerja mesin }\end{array}$ & Rp.6.400.000 & Rp.51.200.000 \\
Biaya pengecetan mesin & Rp.1.000.000 & Rp.8.000.000 \\
Total & Rp.7.400.000 & Rp.59.200.000 \\
\hline
\end{tabular}

Sumber:UD. Singkil Service Manado 2018

Selain biaya operasinal pada beban gaji karyawan dan pengecetan mesin pada Tabel 2, ada terdapat beberapa biaya yang dikeluarkan perusahaan untuk pemeliharaan pada mesin agar mesin menjadi lebih terawat dan agar dapat mengurangi kerugian untuk perbaikan mesin. Biaya pemeliharaan mesin dapat dilihat pada Tabel 3.

Tabel 3. Biaya pemeliharaan pada Mesin Hidrolik

\begin{tabular}{|c|c|c|c|}
\hline Biaya Pemeliharaan & & Per tahun & Selama 8tahun \\
\hline Biaya perbaikan dinamo & & Rp.1.000.000 & Rp. 8.000.000 \\
\hline Biaya biaya obat jamur & & Rp.460.000 & Rp.3.680.000 \\
\hline Biaya selang & & Rp.600.000 & Rp.4.800.000 \\
\hline Biaya oli & & Rp800.000 & Rp6.400.000 \\
\hline Biaya pembersihan & & Rp.300.000 & Rp.2.400.000 \\
\hline Biaya tenaga kerja (preventive maintenance) & & Rp.3.000.000 & Rp.24.000.000 \\
\hline & Total & Rp.6.160.000 & Rp.49.280.000 \\
\hline
\end{tabular}

Sumber:UD. Singkil Service Manado 2018

Dari Tabel 3 biaya pemeliharaan untuk biaya pada mesin sebesar Rp.49.2800.000 dan untuk itu biaya operasional juga yang dikeluarkan perusahaan untuk mesin yang terdapat pada Tabel 2 sebesar Rp. 59.200.000. biaya-biaya tersebut merupakan total 4tahun selama mesin beroperasi pada perusahaan dari tahun 2010 sampai dengan tahun 2018. UD.Singkil Service adalah salah satu perusaaan pencuci mobil oleh karena itu perusahaan dituntut untuk memuaskan pelanggan dan memberikan pelayanan yang terbaik. Untuk melakukan itu semua tentunya ada biaya-biaya agar dapat mesin berjalan dengan baik biaya tersebut yaitu biaya karyawan untuk rawatan mesin dan biaya pada pemeliharaan pada mesin dll.

Tabel 4. Perbandingan mesin lama dan mesin baru

\begin{tabular}{|c|c|c|c|}
\hline Mesin lama & & Mesin baru & \\
\hline Harga perolehan & Rp.64.000.000 & Harga perolehan & 30.000 .000 \\
\hline Umur ekonomis & 8tahun (sisa) & Rencana pemakaian & 12tahun \\
\hline Penjualan tahunan & Rp.429.000.000 & Penjualan tahunan & Rp. 429.000 .000 \\
\hline $\begin{array}{l}\text { Biaya variabel untuk } \\
\text { operasional pertahun }\end{array}$ & Rp.7.400.000 & $\begin{array}{l}\text { Biaya variabel untuk } \\
\text { operasional pertahun }\end{array}$ & Rp.2.000.000 \\
\hline $\begin{array}{l}\text { Biaya pemeliharaan } \\
\text { mesin pertahun }\end{array}$ & Rp.6.160.000 & $\begin{array}{l}\text { Biaya pemeliharaan } \\
\text { mesin pertahun }\end{array}$ & Rp.3.500.000 \\
\hline Nilai jual saat ini & Rp.6.720.000 & Nilai jual saat ini & 0 \\
\hline Nilai buku & Rp.21.333.344 & Nilai buku & 0 \\
\hline
\end{tabular}

Sumber:UD. Singkil Service Manado 2018

Bisa dilihat pada perbedaan dalam menggunakan aktiva lama dan aktiva baru pada Tabel 4 dengan perhitungannya dalam menjual mesin lama pihak UD.Singkil Service Manado akan rugi. Karena; "Harga jual - Nilai Buku = Untung/Rugi" atau Rp.6.780.000 Rp.21.333.344 = Rugi (-Rp.(14.553.344). Daripada merugi pihak perusahaan bisa saja untuk 
dapat mempertahankan mesin yang lama. Caranya, sunk cost adalah nilai buku disebabkan depresiasi sebesar Rp.21.333.344, biaya tersebut seharusnya dikeluarkan karena tidak relevan. Kerugian yang didapatkan jika menjual mesin yang lama yaitu Rp. 6.780.000. Perusahaan akan mendapatkan pendapatan dari mencuci mobil sekitar 8 tahun yaitu Rp3.432.000.000 (8xRp.429.000.000/thn). Perbandingan harga biaya variabel dalam 8 tahun mesin beroperasi yaitu sebesar Rp.59..200.000 (8xRp.7.400.000/tahun), dan mesin baru sebesar Rp.8.000.000 (4xRp.2.000.000). Lewat Tabel 5 bisa mendapatkan informasi yaitu analisis biaya diferensial untuk total pendapatan dari biaya selama 8 tahun untuk mesin lama dan mesin baru.

Tabel 5. Analisis biaya diferensaial untuk keputusan mempertahankan atau mengganti mesin hidrolik

\begin{tabular}{|c|c|c|c|}
\hline Ket & $\begin{array}{c}\text { Total biaya dan } \\
\text { pendapatan selama } 8 \\
\text { tahun }\end{array}$ & & \\
\hline & $\begin{array}{c}\text { Mempertahankan } \\
\text { mesin lama }\end{array}$ & $\begin{array}{c}\text { Biaya Diferensial } \\
\text { Rp }\end{array}$ & $\begin{array}{l}\text { Memngganti mesin } \\
\text { baru }\end{array}$ \\
\hline Penjualan & Rp.3.432.000.000 & -0 & Rp.3.432.000.000 \\
\hline Biaya variabel & (Rp.59.200.000) & Rp.58.000.000 & (Rp.8.000.000) \\
\hline $\begin{array}{l}\text { Biaya depresiasi mesin } \\
\text { baru }\end{array}$ & $-0-$ & (Rp.2.500.000) & (Rp.2.500.000) \\
\hline $\begin{array}{l}\text { Depresiasi mesin lama/ } \\
\text { penghapusan nilai buku }\end{array}$ & (Rp.21.333.344) & $-0-$ & (Rp.21.333.344) \\
\hline Penjualan mesin lama & $-0-$ & Rp.6.720.000 & Rp.6.720.000 \\
\hline Total & Rp.3.351.466.656 & Rp.62.220.000 & Rp.3.406.886.656 \\
\hline
\end{tabular}

Sumber:UD. Singkil Service Manado 2018

Menurut Tabel 5 analisis biaya diferensial pada total yang didapatkan pada biaya se;agi mesin beroperasi 8tahun, ditemukan ada selisih pada nilai atau angka antara mengganti atau mempertahankan mesin baru yaitu Rp.62.220.000 dan biaya selama 8 tahun, ada terdapat selisih nilai tunai bersih antara mempertahankan mesin lama dengan mengganti mesin baru sebesar Cara membuat perhitungannya lebih mudah dengan cara sunk cost mesin lama yaitu :

Rp. 58.000.000 lalu keluarkan biaya masa depan yaitu $\begin{array}{rr}= & \text { Rp. } 2.500 .000 \\ = & \text { Rp.58.000.000 } \\ = & \quad \text { Rp. } 2.500 .000) \\ = & \text { Rp.6.720.000 } \\ = & \text { Rp.62.220.000 }\end{array}$ Perbedaan biaya variabel dalam 8 tahun Penyusutan mesin baru Penjualan Mesin Lama Keuntungan yang didapatkan

Pertumbuhan laba bisa dilihat pada keduanya sebesar Rp. Rp.62.220.000 untuk itu lebih menguntungkan pihak perusahaan dengan membeli mesin yang baru daripada mempertahankannya. Perusahaan mungkin akan merugi. Tetapi ketika perusahaan memilih untuk menggantinya, dia akan mendapatkan laba bersih jauh lebih banyak laba bersihnya Rp. 3.406.886.656. oleh karna itu, ada pertumbuhan laba Rp.62.220.000 lewat pendapatan bersih yang didapatkan mesin lama selama 5 tahun yang hanya seharga Rp.3.351.466.656. Dengan hasil pembahasan diatas, dapat diketahui bahwa biaya Metode biaya diferensial dalam pengambilan keputusan manajemen dapat diterapkan. 


\section{KESIMPULAN DAN SARAN}

\subsection{Kesimpulan}

Penggunaan Akuntansi Informasi Diferensial sangat bermanfaat bagi UD.Singkil Service Manado untuk pihak manajemen dalam memperoleh suatu pertimbangan yang baik dalam pengambilan keputusan pada perusahaan, UD.Singkil Service Manado telah menerapkan biaya diferensial sebagai dan untuk penggunaan sunk cost belum sepenuhnya diterapkan. Biaya diferensial yaitu sebagai suatu pertimbangan jangka panjang kepada penggantian aktiva tetap yaitu mesin cuci mobil tapi sedangkan dengan sunk cost perusahaan dapat mengetahui kerugian dan nilai buku yang terdapat dalam aktiva pada UD. Singkil Service Manado.

\subsection{Saran}

1. Saran yang bisa penulis berikan untuk perusahaan yaitu sebaiknya perusahaan tidak mempertahankan mesin yang lama karena harga untuk memperbaiki dan memelihara mesin hidrolik yang lama lebih besar daripada untuk membeli mesin yang baru, bahkan masa manfaat dari mesin masih cukup lama. Dengan mempertahankan mesin yang lama, perusahaan akan mengeluarkan kas yang cukup banyak. Oleh karena kalau bisa perusahaan disarankan untuk dapat membeli mesin yang baru dan lebih bagus jika ingin menambah jumlah laba dari kegiatan perusahaan.

2. Penulis menyarankan perusahaan sebaiknya menggunakan konsep sunk cost agar mengetahui kerugian dan nilai buku yang terdapat dalam aktiva dan biaya diferensial untuk pengambilan keputusan penggantian aktiva tetap, dengan kedua biaya tersebut bisa membantu manajemen perusahaan dalam mencari informasi mengenai mesin dan bisa dapat merincikan biaya dengan lebih akurat sehingga UD.Singkil Service tidak akan mengalami kerugian.

\section{DAFTAR PUSTAKA}

Afidburhanuddin, 2013. Penelitian kuantitatif dan kualitatif. Maret, 08, 2018.

Ahmad, K. 2014. Akuntansi Manajemen: Dasar-dasar Konsep Biaya dan Pengambilan keputusan . Penerbit: Daerah Istimewa Yogyakarta

Brewer, Garrison, \& Noreen, 2015. Managerial Accounting; Relevant Cost for Decision Making Chapter 11. Oktober 112018

Darsono, A. 2009. Aplikasi Analisis Laporan Keuangan, Penerbit: Liberty, Yogyakarta

Endriyani, E. 2013. Identifikasi dan Analisis Genotiping Rotavirus. (RV) sebagai dasar Pengembangan Diagnosis. Maret, 10, 2018.

George, E. 2012. Incentives for fixed Asset Revaluations: The UK Avidence. Maret, 09, 2018.

Hansen, $\mathrm{R}$ dan M.Mowen. 2005. Akuntansi Manajemen. Jilid ke-1. Edisi ketujuh. Jakarta. Terjemahan Dewi Fitriasari.; Deny Arnos Kwary.

Indrini, E. 2013. Akuntansi Gampang. Penerbit : Dunia Cerdas. Jakarta Timur.

Jimmel, Weygandt, 2014. Accounting Principles. Penerbit : PT. Grasino Jakarta. Terjemahan Hery.

Kuncoro, M. Edisi 4. Metode Riset untuk Bisnis dan Ekonomi: Bagaimana Meneliti dan Menulis Tesis?. Penerbit: Erlangga.

Mursyidi, 2008. Akuntansi Biaya. Penerbit: Refika Aditama, Bandung.

Malawat, G. 2012. Pengaruh Sunk Cost Terhadap Shut Down Firm PT. Adinata._Maret. 12, 2018.

Moleong, Lexy J. (2007) Metodologi Penelitian Kualitatif, Penerbit PT Remaja Rosdakarya. Offset, Bandung. 
Nugroho, Andy H. 2004. Analisis Penerapan Metode Penyusutan Aktiva Tetap dan Pengaruhnya Terhadap Laba Perusahaan. Maret 12, 2018

Prawinegoro. 2009. Akuntansi Manajemen. Edisi Ketiga. Mitra Wacana Media, Jakarta.

Rantung, D. 2014. Penerapan Biaya Diferensial Dalam Pengambilan Keputusan Membeli Atau Memproduksi Sendiri Pada RM. Pangsit Tompaso. Diakses Maret, 12, 2018.

Riahi, Ahmed dan Belkaoui. 2011. Accounting Theory (Teori Akuntansi). Edisi 5. Penerbit : Salemba Empat Jakarta Selatan.

Simamora, S. 2012. Akuntansi Manajemen. Penerbit: Star Gate, Jakarta.

Soermaso S.R 2009. Akuntansi Manajemen Suatu Sudut Pandang. BPFE, Yogyakarta.

Skousen, S. 2010. Intermetiade Accounting. Penerbit : Cincinnati, South Western Terjemah Zaki Baridwan

Susanti, H. 2012. Perlakuan Akuntansi Aset Tetap Terhadap PSAK No.16 Pada Stikes Hang Tuah Tanjungpinang Diakses Maret, 14, 2018 Bandung.

Sugiyono. 2013. Metode Pendidikan Penelitian Pendekatan Kualitatif, Kuantitatif. Penerbit : Alfabeta, Bandung.

Sukardi 2013. Metodologi Penelitian. BPFF, Yogyakarkta

Widodo, J. 2014. Pelantikan Kabinet Kerja. Maret, 10, 2018. 